\title{
Male Circumcision: Unending Debate
}

\section{İbrahim AYDOĞDU, Semih Lütf MiRAPOĞLU, Hüseyin KILINÇASLAN}

Department of Pediatric Surgery, Bezmialem Vakif University School of Medicine, Istanbul, Turkey

\section{ABSTRACT}

Circumcision, foreskin surrounds the penis called the glans prepusyum, mucous-covered means the removal by cutting a piece of skin. This process is probably the most discussed in the history of the world, is one of the oldest surgical procedures. Circumcision is primarily due to religious and cultural beliefs in certain parts of the world, while it is sometimes carried out in the absence of various medical indications. In this article, in our country, circumcision is being done very widely in the literature by examining the latest information on are summarized, and especially the debate about circumcision is intended to examine issues of.

Keywords: Circumcision, children, review

\section{Introduction}

Circumcision is one of the most frequently performed surgeries in the world and one of the oldest in human history (1). It is estimated to date back to 15000 years ago. The fact that the Australian inhabitants performed circumcision with cutting tools made of lighter stones gives an important clue that this procedure persisted from the prehistoric period (2). Circumcision as a surgical procedure was first described about 6,000 years ago in the wall relief of Ankh-Ma-Hor Temple of Ancient Egypt $(2,3)$. It is a divine command that the Jews circumcise infant boys on the eight day of birth with a ceremony that called "bris-milah." However, it has become an indication of being a Muslim for a man, though it is not a binding duty in Islam. $(2,4)$. Approximately $98.6 \%$ of the males in our country are circumcised, and almost all are circumcised for religious or traditional reasons $(1,5)$. Circumcision was initiated for medical reasons in the nineteenth century. In 1891, Remondino suggested that circumcision was a medically beneficial intervention and was effective for prevention against diseases, such as alcoholism, epilepsy, asthma, enuresis, hernia, and gout (6). Surveys in favor of circumcision until the first half of the twentieth century led to the prevalence of medical circumcision, particularly in English-speaking countries, to be performed in the newborn period (7). In 1949, Gairdner questioned the routine circumcision in his article and emphasized the features and importance of the foreskin (8). After this article, pediatric associations in England, Canada, and the USA abandoned recommending routine circumcision in succession, and circumcision rates decreased significantly in these countries (7). With the observation that circumcision significantly reduces urinary tract infections (UTIs) in children, the American Academy of Pediatrics (AAP) in 2012 received a neutral position that left the decision to the family with a new declaration (9). However; because of the low risk of circumcision and its known benefits, and because of the positive explanations provided by AAP, the US Center for Disease Control and Prevention (CDC), World Health Organization (WHO), Joint United Nations Program on HIV/AIDS (UNAIDS), and Voluntary Medical Male Circumcision, it has become widespread in the world today (1). Today, it is estimated that $37.7 \%$ of men in the world are circumcised (1).

\section{Circumcision techniques}

Circumcision, one of the most frequently performed surgeries worldwide, can be performed in different ways. The goal of each method is to achieve the best cosmetic appearance by reducing bleeding or other complications (10). 
Circumcision can be performed through one of three main methods: dorsal slit, shield-clamp (Mogen clamp, Plastibell ${ }^{\oplus}$, Gomco clamp, Zhenxi ring, Tara clamp, Smart clamp, Shang Ring ${ }^{\otimes}$, and Prepex ${ }^{\oplus}$ device), and surgery (Sleeve resection) or through a combination of all three (11). Apart from these, it is also possible to circumcise with hand tools, which use the cutting and burning process simultaneously, called circumcision thermocauter. However, although these devices are practical, they are not recommended for use because they can damage the nerve structure of the penis by the thermocautery effect (12).

Van Haute et al. (10) reported that circumcision performed without suture using 2-octyl cyanoacrylate (2-OCA) tissue adhesive was superior to those performed with standard stitches due to a shorter operating time, less pain, and excellent cosmetic results. In an experimental study, ultracision harmonic scalpel (UHS) was used for circumcision in dogs, and faster operation duration, less bleeding, and less complication rates were reported compared to the conventional circumcision methods (13). Today, monopolar and bipolar electrocauters are widely used for homeostasis in the circumcision procedure. Although no superiority could be found among electrocauters in the studies performed, it was reported that bipolar cauters can be preferred in penile surgery because they are low-energy devices (12).

\section{Circumcision indications}

In the normal anatomy of the penis, the foreskin should be drawn back so that it can reveal the glans penis. The condition in which the foreskin cannot be normally drawn back and in which the glans penis is not visible is called phimosis (14). However, the penis of the majority of newborns is phimotic. With intermittent erections and keratinization of the inner epithelium, the foreskin can be gradually drawn back in childhood; thus, phimosis is usually eliminated (15). In fact, the rate of phimosis decreases to $10 \%$ at the age of 3 years, to $8 \%$ at 6 years, and to $1 \%$ at 16 years (16). Therefore, phimosis in childhood is categorized into two as physiological and pathological. Pathologic or acquired phimosis can cause recurrent balanitis, balanitis xerotica obliterans, and adhesions (14). When the foreskin is slightly retreated in the physical examination; if the tip of the foreskin appears like a scarred ring, it is considered to be pathological phimosis; if it has an appearance of a normal mucosa, it is rather evaluated as physiological phimosis (14). Pathological phimosis, paraphimosis, some penile traumas, and recurrent spinal cord injury (SCI) are considered certain medical indications for circumcision in children (3, 6-9). However, there are also some studies showing that phimosis has no effect on bacterial colonization, and therefore there may not be a definite indication for UTI (17). In addition, physiological phimosis, a very long foreskin, recurrent balanitis and balanoposthitis, and congenital anomalies of the urinary system are relative indications of circumcision $(7,18)$. In a multicenter study, while UTI was found in $63 \%$ of uncircumcised boys with vesicoureteral reflux or pre- natal hydronephrosis, this rate was 19\% in circumcised boys. If a child born with a congenital urological anomaly needs to be circumcised as required in the culture of the residing country, it would be appropriate to undergo circumcision without any delay if such anomalies are detected.

\section{Circumcision contraindications}

Circumcision should not be performed in premature infants, in those with hemorrhagic diathesis in the family or in the baby, and in children with external genital organ anomalies in which the foreskin may be used in future operations. These anomalies include hypospadias, epispadias, buried penis, megalourethra, chordee, webbed penis and penoscrotal fusion $(7,14)$. In case of routine circumcision in the children with these anomalies, skin grafts may be needed for the penis in the future. Particularly, webbed penis and penoscrotal fusion may be missed out during routine examination, and routine circumcision in a baby with penoscrotal fusion may lead to iatrogenic buried penis formation $(7,8)$.

\section{Circumcision complications}

Circumcision is a surgical procedure that is not difficult and can be easily tolerated. Mortality and morbidity is very low after the circumcision performed in compliance with surgical standards. Although the circumcision has many complications, such as infection, hematoma, incomplete excision of the foreskin, suture reaction, stenosis of the external urethral meatus, urethral fistula, extreme excision of the penile skin, and skin bridge adhesion to glans, the most common complication is hemorrhage and the most serious complication is glans amputation. In addition, strict bandage after circumcision may lead to penile gangrene in rare cases (12). It was reported in literature that some patients succumbed to death after severe bleeding and necrotizing fasciitis $(20,21)$. There are significant differences in complication rates detected in circumcision practice, and rates ranging from $0.06 \%$ to $55 \%$ have been reported (22). The complication rates increase up to $85 \%$ in circumcisions performed by traditional circumcisers in developing countries, (23). In a study of 400 cases conducted by Bazmamoun et al. (24), it was concluded that in children under 2 years of age and in newborns, meatal stenosis could develop as a result of the rubbing of unprotected penile tip and external urethral meatus on the diaper or on their own skin, and this could be prevented by putting on Vaseline on the penis tip for 6 months in children with diapers.

\section{Discussion}

In North Africa and the Middle East, which are considered to be the first places for circumcision to begin, the fact that the sands accumulating in the foreskin lead to epidemic balanitis demonstrates that circumcision actually began as a preventive public health measure (25). Indeed, this has been proven by the fact that some of the Australian soldiers who fought in the deserts during the World War II had to be circumcised due to epidemic balanitis (26). Today, the most important accepted benefit of circumcision is that it reduces 
the risk for UTI in children, and this benefit is especially evident in children under 1 year of age $(7,18)$. The fimbrial Escherichia coli, which is the most common cause of UTI in children, adheres to foreskin and not to the glans (27). Since the study of Wiswell et al. (28), a number of studies have been conducted in this regard, and it was found that the incidence of UTI in circumcised children dropped by 3,7-10fold in comparison to uncircumcised children (29). In addition, $10 \%$ of children undergoing UTI have bacteremia and $3-5 \%$ of them have meningitis (31). It should be emphasized that circumcision not only reduces the risk of UTI but also prevents the important and life-threatening complications that the infection may cause. Circumcision is also crucial for protection against local penis infections other than UTI. According to a study, the rate of balanitis was found to be $3.5 \%$ in an uncircumcised boy throughout his life (32). The fact that this rate was found to be $7.1 \%$ in Finland, one of the countries where circumcision is rarely performed, clearly demonstrates the protective feature of circumcision from local penile infections (30). In the context of the human immunodeficiency virus (HIV) protection plan, World Health Organization recommends routine circumcision in the areas where HIV is common. Because the inner layer of the foreskin where HIV-1 target cells are intense is removed during circumcision, significant reduction of HIV positivity has been detected in those who are circumcised $(27,31)$. However, in another study, the fact that circumcised and uncircumcised men did not show a significant difference in HIV positivity weakens the reason for circumcision as protection against HIV infection (32). Other sexually transmitted diseases were also noted to have lower incidence rate of $10 \%$ in circumcised males than in uncircumcised males (25). In recent years, studies have shown that human papilloma virus (HPV), which is the most common sexually transmitted virus, has been found in the penis of uncircumcised men three times more compared to circumcised men (33). Antibodies to chlamydia infection, which is among the major causes of pelvic inflammatory disease, ectopic pregnancy, and infertility and which is the second most frequent sexually transmitted disease after HPV are two times more common in the spouses of uncircumcised males than in the spouses of circumcised ones (27). Even the presence of the foreskin is one of the most accepted factors in penile cancer etiology (34). Although there is no conclusive evidence that smegma is carcinogenic in uncircumcised men, it has been argued that it plays a role in penis cancer due to chronic irritation (35). Thus, circumcision has shown to be effective in preventing penile cancer $(22,36,37)$. However; while the incidence of penile cancer in the United States was found to be $0-2.1$ in 100000 , this ratio was found to be 0.3 in a 100000 in Japan which is a country where circumcision is very rare; this has indicated that the other etiological factors in penile cancer are also very important (38). One of the frequently asked questions about circumcision is the effect of circumcision on sexual life. It is known that circumcised the sexual functions (25). It is known that the foreskin contains specialized nerve endings called "meissner" bodies that are located on the fingers and on the lips (39). Because of this and some other undiscovered effects, some authors argue that removing the foreskin, which is erectile, erogenous, and perhaps protective for the glans penis can reduce sexual pleasure for men (39-41). However, Masters and Johnson did not find any significant difference in the sense of touch of glans between circumcised and uncircumcised men in their study (42). There is not yet a definite, clear, and ideal age proposed for circumcision. Freud emphasized that the interest in the sexual area intensified in the fourth or fifth year of life and that the child discovered the basic anatomical differences and formed the basis of his sexual identity in this phase called the phallic-oedipal period. Thus, the circumcision performed in this period may lead to the fear of losing the sexual organ, which is defined as castration (22). In general, the recommended age for interventions in the genital area is under 18 months. Newborn circumcision, which has been widespread in our country in recent years, also has some advantages (27). There are authors who argue that UTIs are reduced by about 10 -fold and a more aesthetic appearance is provided (22). It has also been reported that circumcision performed during the neonatal period reduces the risk of penile cancer by at least 10 -fold (35). Corticosteroids, epinephrine, androgen, tyrosine and endorphin levels, which have been raised in the blood of newborn infants in the early days as a preparation for stress due to birth trauma, are beneficial for circumcision in this period (27). In circumcisions performed during the newborn period, wound healing is faster and there is no need for suturing. Moreover, complications and costs are significantly lower in circumcisions performed during the neonatal period than in those performed in older ages (43). In circumcision, pain management is very important. Every patient, even though newborn, should be anesthetized. Local anesthesia can be given with local topical creams and/or penile nerve blockade; however, these methods provide about $10 \%$ insuffcient anesthesia (43). Especially in newborns with low birth weight, topical creams are not recommended because they can irritate the skin (43). As a result, circumcision can be performed by local anesthesia in the newborn period, but circumcisions outside this period should be performed under general anesthesia and under advanced operating room conditions if possible (44).

\section{Conclusion}

In conclusion, despite the advantages mentioned above, having been performed for thousands of years, circumcising for protective purposes in addition to medical indications and traditions is still controversial, and this argument is likely to continue for a long time.

Peer-review: Externally peer-reviewed. 
Author Contributions: Concept - İ.A., H.K.; Design - İ.A., H.K.; Supervision - İ.A., H.K.; Funding - İ.A., H.K.; Materials - İ.A., S.L.M.; Data Collection and/or Processing - I.A., S.L.M.; Analysis and/or Interpretation - İ.A., H.K.; Literature Review - İ.A., H.K.; Writing - İ.A., S.L.M.; Critical Review - İ.A., H.K.; Other - İ.A., H.K.

Conflict of Interest: No conflict of interest was declared by the authors.

Financial Disclosure: The authors declared that this study has received no financial support.

\section{References}

1. Morris BJ, Wamai RG, Henebeng EB, Tobian AA, Klausner JD, Banerjee J, et al. Estimation of country-specific and global prevalence of male circumcision. Popul Health Metr 2016; 14: 4. [CrossRef]

2. Bayat AH. Tıp tarihi. Genişletilmiş 2. Baskı. İstanbul: Merkezefendi Geleneksel Tıp Derneği; 2010.

3. Dunsmuir WD, Gordon EM. The history of circumcision. BJU Int 1999; 83: 1-12. [CrossRef]

4. Sari N, Büyükünal SN, Zülfikar B. Circumcision ceremonies at the Ottoman palace. J Pediatr Surg 1996; 31: 920-4. [CrossRef]

5. Söylet Y. Çocuk cerrahisinde en sık uygulanan cerrahi girişimler (kasık kanalı ameliyatları, sünnet, hipospadias). STE Online 2003; 35: 33-40.

6. Remondino PC. History of circumcision from the earliest times to present. Phialadelphia, FA Davis; 1891.

7. Lerman SE, Liao JC. Neonatal circumcision. Pediatr Clin North Am 2001; 48: 1539-57. [CrossRef]

8. Gairdner D. The fate of foreskin. BMJ 1949; 2: 200-3. [CrossRef]

9. American Academy of Pediatrics Task Force on Circumcision. Male circumcision. Pediatrics 2012; 130: e756-85. [CrossRef]

10. Van Haute C, Tailly T, Klockaerts K, Ringoir Y. Sutureless circumcision using 2-Octyl cyanoacrylate results in more rapid and less painful procedures with excellent cosmetic satisfaction. J Pediatr Urol 2015; 11: 147.e1-5. [CrossRef]

11. Abdullahi Abdulwahab-Ahmed, Ismaila A. Mungadi. Techniques of male circumcision J Surg Tech Case Rep 2013; 5: 1-7. [CrossRef]

12. Şencan A, Çayırlı H, Şencan A. Sünnet teknikleri. CBU-SBED 2015; 2: 86-90.

13. Peng $\mathrm{M}$, Meng $\mathrm{Z}$, Yang $\mathrm{ZH}$, Wang $\mathrm{XH}$. The ultrasonic harmonic scalpel for circumcision: experimental evaluation using dogs. Asian J Androl 2013; 15: 93-6. [CrossRef]

14. McGregor TB, Pike JG, Leonard MP. Pathologic and physiologic phimosis: approach to the phimotic foreskin. Can Fam Physician 2007; 53: 445-8.

15. Orsola A, Caffaratti J, Garat JM. Conservative treatment of phimosis in children using a topical steroid. Urology 2000; 56: 307-10. [CrossRef]

16. Oster J. Further fate of the foreskin. Incidence of preputial adhesions, phimosis, and smegma among Danish schoolboys. Arch Dis Child 1968; 43: 200-3. [CrossRef]

17. Irkilata L, Aydin HR, Aydin M, Gorgun S, Demirel HC, Adanur S, Akgunes E, Atilla A, Atilla MK. Preputial bacterial colonisation in uncircumcised male children: Is it related to phimosis? J Pak Med Assoc 2016; 66: 312-5.

18. Hutcheson JC. Male neonatal circumcision: indications, controversies and complications. Urol Clin North Am 2004; 31: 461-7. [CrossRef]

19. Herndon CD, McKenna PH, Kolon TF, Gonzales ET, Baker LA, Docimo SG. A multicenter outcomes analysis of patients with neonatal reşux presenting with prenatal hydronephrosis. J Urol 1999; 162: 12038. [CrossRef]

20. Paediatric Death Review Committee: Office of the Chief Coroner of Ontario. Circumcision: A minor procedure? Paediatr Child Health 2007; 12: 311-2.

21. Sullivan P. Infant's death another nail in circumcision's coffin, group says. CMAJ 2002; 167: 789.
22. İzgi MC. Ethical evaluation of non-therapeutic male circumcision. Turk Psikiyatri Derg 2015; 26: 204-12.

23. Cankorkmaz L, Çetinkaya S, Köylüoğlu G. Pratisyen hekimlerin sünnetle ilgili bilgi düzeyleri. Balkan Med J 2011; 28: 264-8.

24. Bazmamoun H, Ghorbanpour M, Mousavi-Bahar SH. Lubrication of circumcision site for prevention of meatal stenosis in children younger than 2 years old. Urol J 2008; 5: 233-6.

25. Bhattacharjee PK. Male circumcision: an overview. Afr J Paediatr Surg 2008; 5: 32-6. [CrossRef]

26. Hutson JM. Circumcision: a surgeon's perspective. J Med Ethics 2004; 30: 238-40. [CrossRef]

27. Schoen EJ. Should newborns be circumcised? Yes. Can Fam Physician 2007; 53: 2096-8.

28. Wiswell TE, Smith FR, Bass JW. Decreased incidence of urinary tract infections in circumcised male infants. Pediatrics 1985; 75: 901-3. [CrossRef]

29. Houle AM. Circumcision for all: the pro side. Can Urol Assoc J 2007; 1: 398-400.

30. Cameron DW, Simonsen JN, D'Costa LJ, Ronald AR, Maitha GM, Gakinya MN, et al. Female to male transmission of human immunodeficiency virus type 1: risk factors for seroconversion in men. Lancet 1989; 2: 403-7. [CrossRef]

31. Reynolds SJ, Shepherd ME, Risbud AR, Gangakhedkar RR, Brookmeyer RS, Divekar AD, et al. Male circumcision and risk of HIV-1 and other sexually transmitted infection in India. Lancet 2004; 363: 103940. [CrossRef]

32. Van Howe RS. Circumcision as a primary HIV preventive: extrapolating from the available data. Glob Public Health 2015; 10: 607-25. [CrossRef]

33. Castellsagué X, Bosch FX, Muñoz N, Meijer CJ, Shah KV, de Sanjose S, et al. International Agency for Research on Cancer Multicenter Cervical Cancer Study Group. Male circumcision, penile human papillomavirus infection, and cervical cancer in female partners. N Engl J Med 2002; 346: 1105-12. [CrossRef]

34. Bunker CB. Topics in penile dermatology. Clin Exp Dermatol 2001; 26: 469-79. [CrossRef]

35. Hayashi Y, Kojima Y, Mizuno K, Kohri K. Prepuce: phimosis, paraphimosis, and circumcision. Scientific World Journal 2011; 11: 289-301. [CrossRef]

36. Schoen EJ, Oehrli M, Colby C, Machin G. The highly protective effect of newborn circumcision against invasive penile cancer. Pediatrics 2000; 105: 36. [CrossRef]

37. Schoen EJ. The relationship between circumcision and cancer of the penis. CA Cancer J Clin 1991; 41: 306-9. [CrossRef]

38. Williams N, Kapila L. Complications of circumcision. Br J Surg 1993; 80: 1231-6. [CrossRef]

39. Morgan WKC. The rape of the phallus. JAMA 1965; 193: 123-4. [CrossRef]

40. Bronselaer GA, Schober JM, Meyer-Bahlburg HF, T'Sjoen G, Vlietinck $\mathrm{R}$, Hoebeke PB. Male circumcision decreases penile sensitivity as measured in a large cohort. BJU Int 2013; 111: 820-7. [CrossRef]

41. Viens AM. Value judgment, harm, and religious liberty. J Med Ethics 2004; 30: 241-7. [CrossRef]

42. Masters WH, Johson VE. Human sexual response. Boston: Little Brown and Company; 1996: 189-91.

43. Simpson E, Carstensen J, Murphy P. Neonatal Circumcision: new recommendations \& implications for practice. Missouri Medicine 2014; 111: 222-30.

44. Micha G, Samanta E, Damigos D, Petridis A, Mavreas V, Livanios S. Impact of an anesthesia discharge scoring system on postoperative monitoring after circumcision in children: a randomized trial. Eur J Pediatr Surg 2009; 19: 293-6. [CrossRef] 